\title{
A 2019. évi ARIA kezelési irányelvek magyar adaptációja és a hazai alkalmazás lehetőségei allergiás rhinitisben
}

\author{
Kraxner Helga dr. ${ }^{1}$. Hirschberg Andor dr. ${ }^{2}$ - Nékám Kristóf dr. ${ }^{3}$ \\ ${ }^{1}$ Semmelweis Egyetem, Általános Orvostudományi Kar, Fül-Orr-Gégészeti és Fej-Nyaksebészeti Klinika, Budapest \\ ${ }^{2}$ Észak-Közép-budai Centrum, Új Szent János Kórház és Szakrendelő, Fül-Orr-Gége és Szájsebészeti Osztály, \\ Budapest \\ ${ }^{3}$ Budai Irgalmasrendi Kórház, Allergológia és Immunológia Szakambulancia, Budapest
}

\begin{abstract}
Az allergiás betegségekben szenvedő emberek száma világszerte, köztük Magyarországon is növekszik. Az egészségügyi ellátórendszerek azon dolgoznak, hogy minél hatékonyabban tudják felhasználni a rendelkezésre álló forrásokat. Az Allergic Rhinitis and its Impact on Asthma (ARIA) szervezet célja az allergiás náthában szenvedő betegek ellátásának javítása, szakmai ajánlások készítése, aktualizálása. Ennek egyik módja integrált betegellátási utak kidolgozása. Célunk ezek hazai elérhetővé tétele, az ajánlások széles körű elterjesztése az Európai Unió (EU) többi tagállamához hasonlóan Magyarországon is. Az ARIA más nemzetközi innovatív szervezetek bevonásával olyan integrált betegellátási utakat fejlesztett ki, amelyek allergiás nátha, esetleg társbetegsége, az asztma esetén támogatják a kezelést. Ezeket újgenerációs irányelvek kidolgozása útján alkották, amelyekhez felhasználták a mobiltechnológiából és pollenkamra-vizsgálatokból származó valós evidenciákat is. A gyógyszeres terápia optimalizálásához a vizuális analóg skálán alapuló, úgynevezett Mobil Légúti Figyelő Hálózat algoritmusát digitalizálták, és valós evidenciák felhasználásával tovább finomították. Allergén immunterápiára az ARIA a világon elsőként dolgozott ki integrált betegellátási utakat 2019-ben. A kezelési irányelvekhez való adherenciaszint alacsony, a betegek a tüneteik erőssége alapján módosítják a kezelést. A flutikazon-propionát-azelasztin kombináció hatása erősebb az intranasalis kortikoszteroidokénál, míg az utóbbi hatásosabb az oralis $\mathrm{H}_{1}$-antihisztaminoknál. A mobiltelefonokban tárolt elektronikus napló vagy más 'mobile health' (mHealth) eszközök használata segíti a betegek kiválasztását allergén immunterápiára. Az ARIA által javasolt algoritmus megfelelőnek mutatkozott az allergiás rhinitis kezelésére, ezért ezek az irányelvek bekerülnek integrált betegellátási utakba, és részét fogják képezni az EU Egészségügyi és Élelmiszer-biztonsági Főigazgatósága digitalizált, személyközpontú gondozási anyagainak. Az allergén immunterápia hatékony az inhalatív allergének által okozott allergiás betegségekben, alkalmazását azonban korlátozni kell gondosan válogatott betegekre.

Orv Hetil. 2020; 161(49): 2059-2071.
\end{abstract}

Kulcsszavak: allergiás nátha, allergénspecifikus immunterápia, integrált betegellátási utak, valós evidencia, MASKalgoritmus

\section{Hungarian adaptation and launch of the 2019 ARIA care pathways of allergic rhinitis in Hungary}

The number of allergic patients is increasing all over the world, also in Hungary. Delivering effective and cost-effective health care is essential for all health care systems. ARIA (Allergic Rhinitis and its Impact on Asthma) aims to improve the care of patients who suffer from allergic rhinitis by setting up guidelines and updating them. Development of ICPs (integrated care pathways) can play an essential role in attaining this goal. Our aim is to make ICP-s developed by ARIA available also in Hungary, as is already the case in other countries of the European Union (EU). Together with other international initiatives, ARIA has worked out digitally-enabled ICPs to support care in allergic rhinitis and comorbid asthma. ICPs are based on new-generation guidelines using RWE (real-world evidence) from chamber studies and mobile technology. The MASK (Mobile Airways Sentinel NetworK) algorithm - based on visual analogue scale - was digitalized to support pharmacotherapy, and was refined by using RWE. ARIA was the first to develop ICPs for allergen immunotherapy (AIT) in 2019. Based on MASK data, patients did not follow guidelines and their adherence to treatment was poor. Patients would modify their treatments, depending on the disease control. The effect of fluticasone propionate-azelastine combination is superior to intranasal corticosteroids which are 
superior to oral $\mathrm{H}_{1}$-antihistamines. Electronic diaries obtained from cell phones and other 'mobile health' (mHealth) devices help select patients for AIT. The ARIA algorithm for AR was found appropriate and no change is necessary. These guidelines will inform ICPs and will be included in the DG Santé digitally-enabled, person-centred care system. AIT is an effective treatment for allergic diseases caused by inhaled allergens. Its use should, however, be restricted to carefully selected patients.

Keywords: allergic rhinitis, allergen-specific immunotherapy, integrative care pathways, real-world evidence, MASK algorithm

Kraxner H, Hirschberg A, Nékám K. [Hungarian adaptation and launch of the 2019 ARIA care pathways of allergic rhinitis in Hungary]. Orv Hetil. 2020; 161(49): 2059-2071.

(Beérkezett: 2020. május 24.; elfogadva: 2020. június 23.)

\section{Rövidítések}

$\mathrm{AEC}=($ allergen exposure chamber $)$ allergénexpozíciós kamra; AIT = allergén-immunterápia; $\mathrm{AR}=$ (allergic rhinitis $)$ allergiás nátha; ARIA = (Allergic Rhinitis and its Impact on Asthma) allergiás náthával és asztmára gyakorolt hatásával foglalkozó szervezet neve; Aze = azelasztin; DB-PC-RCT = (double-blind, placebo-controlled, randomized trial) kettős vak-, placebokontrollált randomizált vizsgálat; EIT $=($ European Institute for Innovation and Technology) Európai Innovációs és Technológiai Intézet; EMA $=($ European Medicines Agency) Európai Gyógyszerügynökség; EU = Európai Unió; FP = flutikazon-propionát; GINA = (Global Initiative for Asthma) nemzetközi szervezet asztmaajánlások kidolgozására; GRADE = (Grading of Recommendations Assessment, Development and Evaluation) módszer szakmai ajánlások értékelésére, fejlesztésére, megítélésére; ICP = (integrated care pathway) integrált betegellátási út; $\operatorname{IgE}=$ immunglobulin-E; INAH = intranasalis antihisztamin; INCS = (intranasal corticosteroid) intranasalis kortikoszteroid; MACVIA = (Fighting Chronic Diseases for Active and Healthy Ageing) krónikus betegségek elleni küzdelem az aktív és egészséges öregedésért (az Európai Innovációs Partnerség keretében futó program $) ;$ MASK = (Mobile Airways Sentinel networK $)$ Mobil Légúti Figyelő Hálózat; mHealth $=$ (mobile health $)$ mobil-egészségalkalmazás; MPAzeFlu = flutikazon-propionát (FP)-azelasztin (Aze) kombináció (intranasalis kortikoszteroid + intranasalis antihisztamin fix kombinációja, INCS + INAH) $; \mathrm{MPR}=($ medication possession ratio) gyógyszerfelhasználási arány; NIH = (National Institute of Health $)$ az Egyesült Államok Nemzeti Egészségügyi Intézete; NPP = (named patient product) személyre szóló termék; OTC = (over-the-counter drug) a patikában recept nélkül is elérhetó gyógyszer; PDC $=$ (proportion of days covered) lefedett napok aránya; PEI = (Paul Ehrlich Institute $)$ Paul Ehrlich Kutatóintézet, Langen, Németország; POLLAR = (Impact of Air Pollution on Asthma and Rhinitis) a légszennyezés hatása az asztmára és a náthára; RCT $=$ (randomized controlled trials) randomizált kontrollált vizsgálat; RWE $=$ (real-world evidence) valós evidencia; SCIT = subcutan immunterápia; $\mathrm{SDM}=$ (shared decision-making) tájékozott döntéshozatal; SIT = specifikus immunterápia; SLIT = sublingualis immunterápia; VAS = vizuális analóg skála; $\mathrm{WHO}=$ (World Health Organization) Egészségügyi Világszervezet
Minden társadalomban gyorsan növekszik az allergiás betegségek okozta költség és teher, ami szükségessé teszi az eddigi ellátási stratégiák megváltoztatását és az egészségügyi ellátórendszer átalakítását integrált ellátássá [1]. Párizsban 2018. december 3-án tartottak egy konferenciát az allergiás és más krónikus légúti betegségek ellátásáról [2]. Ezt két szervezet, a MASK (Mobile Airways Sentinel NetworK) $[3,4]$ és a POLLAR (Impact of Air Pollution on Asthma and Rhinitis, EIT Health) [5] szervezte, együttmúködésben szakmai és betegszervezetekkel. A konferencia feladata az ún. 'real-life integrated care pathways' (ICPs) - integrált ellátási utak a valóságban értékelése volt a digitalizált, integrált, személyközpontú ellátásban, allergiás nátha és asztma multimorbiditás esetén, a környezeti expozíció figyelembevételével [3].

Az ICP-k strukturált, multidiszciplináris ellátási tervek, amelyek a betegellátás kulcslépéseit foglalják magukba. Támogatják az irányelvek javaslatainak beillesztését a helyi protokollokba és alkalmazásukat a klinikai gyakorlatban. A légúti ICP-k kidolgozása (integrated care pathways for airway diseases) [6] volt az első lépés a rhinitis és az asztma multimorbiditásra vonatkozó ICP-k kialakításának irányába [7-9].

Allergiás náthában (AR) sürgősen szükség van újgenerációs irányelvek kidolgozására a farmakoterápiára vonatkozóan, valamint ICP-k megalkotására az allergén-immunterápiát (AIT) illetően is. Két külön dokumentum jelent meg a párizsi konferenciát követően [10]. Gyakorlati összefoglaló látható az 1. ábrán [9]. A különböző országok vagy régiók ezt még változtathatják annak érdekében, hogy a dokumentumok következtetései a helyi viszonyokra és egészségügyi rendszerre adaptálhatók legyenek.

\section{Magyarországi helyzet}

\section{Prevalencia és jelentöség}

Magyarországon körülbelül 2 millió fơre becsülik az allergiás betegek számát, ami a lakosság 20-25\%-os érin- 


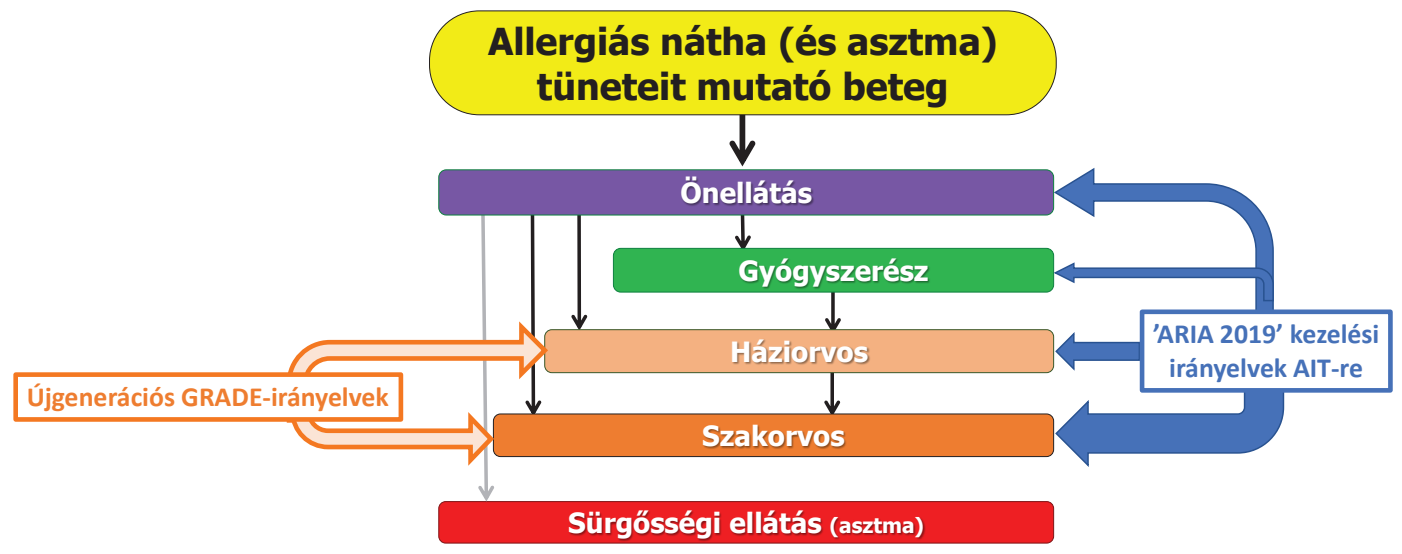

1. ábra

A jelen dokumentumban szerepló, újgenerációs ARIA kezelési irányelvek [9]
ARIA = allergiás náthával és asztmára gyakorolt hatásával foglalkozó szervezet neve

tettségét jelenti, míg világszerte a prevalencia országonként változik, 10-40\% között mozog. A WHO előrejelzése alapján 2050-re minden második ember allergiás náthában szenvedhet. Egy 2016-os magyarországi reprezentatív felmérés szerint a parlagfü-allergia előfordulása a 18 év fölötti lakosság körében 22\% [11], míg az általános iskolába járó gyermekek körében végzett vizsgálat során a budapesti iskolások között az AR előfordulása 14,9\%-osnak mutatkozott 2007-ben, 23,5\%-osnak 2013-ban, ami a prevalencia szignifikáns növekedését mutatja ezen időszak alatt $[12,13]$. Ennek tükrében népegészségügyi problémáról van szó, az allergiás betegek aránya folyamatosan emelkedik. A valós számot nehéz meghatározni, tekintve az atópiás alkat különböző megnyilvánulási formáit, súlyossági fokozatait. Ennek megfelelően a betegek ellátása is különböző szinteken zajlik, az alapellátást végző háziorvostól kezdve a specifikus szakambulanciákig, súlyos esetben kórházi ellátásig.

\section{Specifikus rizikófaktorok}

A magyarországi rizikófaktorok hasonlóak az Európa más országaiban tapasztaltakhoz. Az életmód megváltozása, a városiasodás, a megnövekedett környezetszenynyezés, a táplálkozás megváltozása, a családok méretének, a testvérek számának csökkenése, a higiénés szempontok előtérbe kerülése egész Európában tapasztalható, így Magyarországon is. Emellett számolni kell a flóra és a fauna változásával is, amelyek közül magyar viszonylatban kiemelendő a parlagfü jelentősége. A növény elszaporodásával arányosan nőtt az arra allergiás betegek száma, ma a felnőtt magyar lakosság körében az egyik domináns allergénnek tekinthető [14].

\section{Egészségügyi ellátás}

Magyarországon az AR-betegek egy része - más európai országokhoz hasonlóan - nem fordul orvoshoz, a patiká- ban recept nélkül elérhető gyógyszerekkel saját magát kezeli, a gyógyszerész javaslata alapján. Amennyiben orvoshoz fordul, az enyhe, intermittáló tünetekkel rendelkező betegek ellátása az alapellátás keretei között, háziorvosi szinten történik. A kórtörténet felvételét és a fizikális vizsgálatot követően a háziorvos általában tüneti terápiát ajánl, valamint életmódbeli tanácsokkal látja el a beteget. Ugyanakkor a közepes/súlyos tartós panaszok, a nem megfelelő tüneti kontroll, a differenciáldiagnosztikai megfontolások és a specifikus diagnosztika igénye szükségessé teszi a fül-orr-gégészeti, allergológiai szakorvosi vizsgálatot is [15]. Csak specifikus diagnosztikát követően kerülhet sor az allergiás rhinitis oki kezelését jelentő allergén immunterápiára. Az ily módon kezelt betegek aránya Magyarországon sajnálatosan alacsony, aminek okai fóként a finanszírozásban keresendők. Közfinanszírozott módon ez a terápia csak nagyon korlátozott esetben, kevés beteg számára érhető el.

\section{Az ARIA szerepe}

Az ARIA (Allergic Rhinitis and its Impact on Asthma) a megalakulása óta célul tűzte ki az AR evidenciaalapú diagnosztikai és terápiás szakmai útmutatóinak, irányelveinek kidolgozását és rendszeres frissítését. Magyarországon is időról időre megjelenik a legfrissebb, magyar nyelvű adaptáció, amelynek alapján a betegek diagnosztikája és terápiája történik, amennyiben a beteg orvoshoz fordul.

Az alábbiakban részletezett újgenerációs ARIA-ajánlások tekintetében szintén azok hazai bevezetése a cél. Ezt hátráltatja azonban, hogy az okoseszközökre letölthető applikáció - amely az újgenerációs ajánlások alapját képezi, és segíti a valós evidenciákon alapuló, minél inkább személyre szabott terápia megvalósítását allergiás náthában - hazánkban jelenleg még nem érhető el. Reményeink szerint a közeli jövőben ez változik, és az applikáció elérhetővé válik mind a betegek, mind a kezelést irányító orvosok - háziorvosok, fül-orr-gégészek, allergológu- 
sok, pulmonológusok -, illetve a gyógyszerészek számára is. Az applikációval új típusú betegvezetésre, személyre szabott terápiára nyílik majd lehetőség, az egyéni mérlegelés maximális előtérbe helyezésével. Ez hozzájárulhat a terápiás hatékonyság fokozásához, a terápia elfogadottságának növeléséhez és az életminőség javításához.

\section{Újgenerációs ARIA-GRADE iránymutatók [9]}

Az allergiás betegek számára a megfelelő farmakoterápia megválasztásának célja a megfelelő tüneti kontroll elérése [16].

A GRADE (Grading of Recommendations Assessment, Development and Evaluation) módszertana figyelembe vesz minden tanulmánytípust, míg a irányelvek megalkotói gyakran csak a randomizált kontrollált vizsgálatokból (randomized controlled trials, RCT-k) származó evidenciákra szorítkoznak. Ezen túlmenően a GRADE olyan evidenciákat is tekintetbe vesz, mint a fontosság, az előnyben részesítés, az elfogadottság és a megvalósíthatóság, valamint azt is értékeli, hogy a megállapítások mennyire közvetlenek. Egyre inkább az a tendencia, hogy 'real-world' (valós, tehát életszerú) evidenciákat (RWE) biztosítsunk a klinikai gyakorlat számára. Ideális esetben a két evidenciatípust együttesen kellene figyelembe venni.

A párizsi konferencia során újgenerációs irányelveket dolgoztak ki az AR gyógyszeres terápiájára a már létező, GRADE-alapú AR-irányelvek felhasználásával [17-19], amelyeket mobiltechnológián $[3,5,20,21]$ és pollenkamra-vizsgálatokon alapuló RWE-k segítségével teszteltek. Ezeket az ajánlásokat az AR kezelésére szolgáló, konszenzusbizottság által előterjesztett MASK-algoritmus finomítására használták fel [22].

\section{$A z A R I A-I C P-k$ fejlesztése során figyelembe vett evidenciák}

\section{MASK-algoritmus az AR gyógyszeres kezelésére}

A MASK-algoritmus vizuális analóg skálán alapul (VAS), amelyet abból a célból alkottak [22], majd digitalizáltak, hogy útmutatást adjon az AR 'step-up' (felépítő) vagy 'step-down' (leépítő) terápiájára vonatkozóan. Ezt azonban mindig az adott országban rendelkezésre álló gyógyszerekhez és lehetőségekhez kell igazítani $(2 / a$ és $2 / b$ ábra).

\section{AZ ARIA 2010., 2016. évi revíziója és a 'US Practice Parameters 2017'}

Habár csak nagyon kevés, RCT-n alapuló, az egyes gyógyszereket egymással egy az egyben összehasonlító vizsgálat áll rendelkezésre [23, 24], az AR gyógyszeres terápiáinak összehasonlítását áttekintő cikkek (review-k) [16] és irányelvek [17-19, 22] is indítványozták. Egy ún. egészségtechnológiai becslés kiértékelése során arra a következtetésre jutottak, hogy a legtöbb, AR-ban használatos gyógyszeres kezelésnek hasonló a hatása [25]. Az említett vizsgálat azonban túlságosan merev, kötött metodikán alapult, ami nem tette lehetővé az egyes gyógyszeres terápiák hatékonyságának finomabb megkülönböztetését.

Az ARIA 2016. évi revíziója [18] és a 'US Practice Parameters 2017' [19], amelyeket egymástól függetlenül dolgoztak ki, ugyanazt a metodikai megközelítést alkalmazta: a GRADE-t. Érdekes módon ugyanazokat a kérdéseket vizsgálták. Két fő kimenetet figyeltek a mérsékelt/súlyos AR kezelésében: a kezelés hatékonyságát, valamint a hatás gyorsaságát (1. és 2. táblázat). Következtetéseik hasonlóak.

Az ARIA 2016. évi revíziója [18] és a 'US Practice Parameters 2017' [19] foóként olyan RCT-ken alapul, amelyek a MASK-algoritmust támogatják [22].

1. táblázat |Az 'ARIA 2016' általános ajánlásai [18]

1. SAR-ban szenvedő betegeknek vagy az INCS + OAH kombinációt ajánljuk, vagy választható az INCS-monoterápia is, a potenciális terápiás haszon azonban nem feltétlenül indokolja további anyagi teher vállalását.

2. PAR-ban szenvedő betegeknek az INCS-monoterápia ajánlott inkább, mint az INCS + OAH kombinációja.

3. SAR esetén ajánlhatjuk az INCS + INAH kombinációját is az INCS-monoterápiával szemben, attól függően, hogy a beteg melyiket szeretné. A kezelés kezdetén (első 2 hét) az INCS + INAH kombinációja gyorsabban hathat, mint az INCS önmagában, ezért a páciensek a kombinációs kezelést előnyben részesíthetik. Olyan szabályozás esetén, amelynél a kombinációs terápia nem jelent nagy pluszköltséget, indokolt választás lehet.

4. PAR esetén vagy az INCS + INAH kombinációját ajánljuk, vagy az INCS monoterápiát.

Az összes fenti ajánlás evidenciaszintje alacsony [2, 3] vagy nagyon alacsony $[1,4]$ volt.

ARIA = allergiás náthával és asztmára gyakorolt hatásával foglalkozó szervezet neve; INAH = intranasalis antihisztamin; INCS $=$ intranasalis kortikoszteroid; $\mathrm{OAH}=$ oralis antihisztamin; $\mathrm{PAR}=$ perenniális allergén által kiváltott, perzisztáló allergiás nátha; $\mathrm{SAR}=$ szezonális allergén által kiváltott intermittáló allergiás nátha
2. táblázat A 'US Practice Parameters' legfontosabb klinikai ajánlásai [19] SAR esetén az orrtünetek bevezető kezelésére, 12 évesnél idő- sebb betegeknél

- Rutinszerúen INCS-monoterápia ajánlott inkább, mint INCS és oralis $\mathrm{H}_{1}$-antihisztamin.

- INCS ajánlott inkább, mint LTRA (15 éves vagy annál idősebb betegeknek).

- Mérsékelt/súlyos tünetek esetén INCS és INAH kombinációja ajánlható.

INAH $=$ intranasalis antihisztamin; INCS $=$ intranasalis kortikoszteroid; LTRA = leukotriénreceptor-antagonista; SAR = szezonális allergén által kiváltott intermittáló allergiás nátha 
a)

b)

\section{A kontrolláltság felmérése kezelt, tünetekkel rendelkező betegekben}

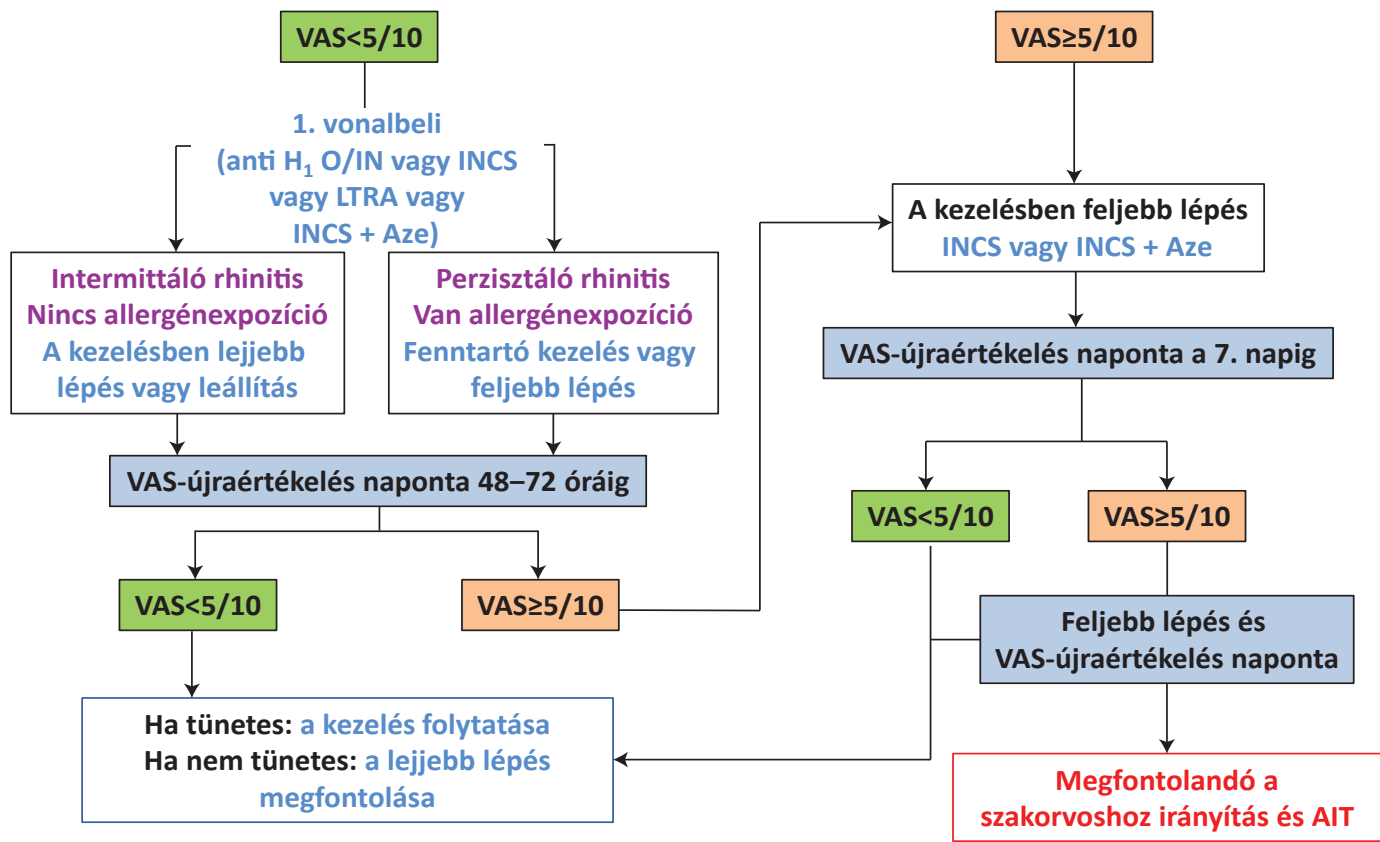

2/a-b ábra | A lépcsőzetes terápia algoritmusa kezeletlen/kezelt betegeken a vizuális analóg skála felhasználásával (kamaszok és felnőttek) (a [22] alapján). A javasolt algoritmus figyelembe veszi a terápiás lépcsőket és a beteg preferált VAS-szintjeit, arányszámban kifejezve. Ha a szemtünetek maradnak, miután elkezdtük a kezelést, intraocularis kezelés hozzáadása szükséges

AIT = allergén-immunterápia; IN = intranasalis; INCS + Aze = intranasalis kortikoszteroid + azelasztin (intranasalis antihisztamin) kombinációja (flutikazon-propionát + azelasztin fix kombinációja, MPAzeFlu); LTRA = leukotriénreceptor-antagonista; O = oralis; VAS = vizuális analóg skála
A gyógyszeres kezelések hatásának gyorsasága

Három vizsgálati típus alapján becsülhető az AR különböző gyógyszeres kezeléseinek hatáskezdete [26]: ezek a standard fázis III. kettős vak-RCT-k, a parkvizsgálatok, valamint az allergénexpozíciós kamrás (AEC-) vizsgálatok. Az AEC-k előnye a gyógyszeres kezelések hatáskez- detének vizsgálata során, hogy itt a hatás perceken belül demonstrálható [27].

Ontariói [28, 29] és bécsi pollenkamra-vizsgálatok során [30-32] számos oralis és intranasalis készítményt teszteltek. Az ontariói kamravizsgálatok gyors hatáskezdetet mutattak ki az azelasztin és kombinációi, például 
- A betegek nem követték az irányelveket, gyakran saját magukat kezelték.

- A kezeléshez való adherencia szintje alacsony.

- A betegek a leginkább a tüneteik erőssége alapján kezelik magukat a betegség kontrolljától függóen, és fokozzák a kezelést, ha nincsenek jól. Az addicionális terápia azonban nem javítja a kontrollt.

- Az INCS + INAH (például MPAzeFlu) hatása erôsebb az INCSnél, míg az utóbbi hatásosabb az oralis $\mathrm{H}_{1}$-antihisztaminoknál.

$\mathrm{AR}=$ allergiás nátha; INAH $=$ intranasalis antihisztamin; INCS = intranasalis kortikoszteroid; MPAzeFlu = intranasalis kortikoszteroid + intranasalis antihisztamin fix kombinációja; $\mathrm{RWE}=$ valós evidencia

az MPAzeFlu (flutikazon-propionát-azelasztin kombináció) esetében. Más intranasalis $\mathrm{H}_{1}$-antihisztaminoknak lassúbb volt a hatáskezdete. Az intranasalis kortikoszteroidok (INCS) (önmagukban vagy oralis $\mathrm{H}_{1}$-antihisztaminnal kombinálva) 2 órán belül nem effektívek [28]. A bécsi pollenkamra-vizsgálatok azt mutatták, hogy az azelasztin és a levokabasztin/flutikazon-furoát a leggyorsabban ható szerek, összehasonlítva az oralis $\mathrm{H}_{1}$-antihisztaminokkal vagy INCS-ekkel.

'Real-world' (valós) evidenciák a mobiltechnológia felhasználásával

Az újgenerációs ARIA-irányelvek a GRADE-ajánlásokat tesztelték RWE-alapon, az mHealth-eszközök adatainak felhasználásával az ajánlások és a MASK-algoritmus megerôsítésére vagy további finomítására. Bár sok mHealth- eszköz érhető el AR-ra, csak a MASK szolgáltat olyan adatokat a gyógyszeres kezelésre vonatkozóan, amelyeket RWE-szinten fel lehet használni [3]. Az eredményeket a 3. táblázat mutatja.

$\mathrm{Az}$ adherenciát direkt módon nem lehet bizonyítani, mivel a MASK-felhasználók nem szolgáltatnak naponta adatokat, és nem biztos, hogy minden, általuk használt gyógyszert jelentenek. A másodlagosan becsült adherenciát a módosított gyógyszerfelhasználási arány (medication possession ratio, MPR) és a lefedett napok aránya (proportion of days covered, PDC) alapján kisebbnek találták, mint 5\%.

\section{A mobiltechnológia korlátai}

Mint minden olyan vizsgálat esetében, amely a résztvevők adatainak felhasználásán alapul, potenciális hibák előfordulhatnak. Ideértendők a lehetséges mintavételi torzítások vagy a kimenet hibás besorolása, valamint etikai okokból az adott beteg (vagy a nap) sajátosságairól csak nagyon kevés információ áll rendelkezésre. Az alkalmazásfelhasználók nem alkotnak reprezentatív csoportot az összes AR-páciensre vonatkozóan.

A MASK adott napokat vetett alá keresztmetszeti (cross-sectional) analízisnek [3], mivel a kezelésnek nincs egyértelmúen meghatározott módja, és a longitudinális vizsgálat sem volt megvalósítható (tekintettel arra, hogy a felhasználók általában csak időszakosan használják az applikációt). Az AR-t nem támasztotta alá orvosi diagnózis, de a legtöbb felhasználónak nagy valószínúséggel van rhinitise (allergiás vagy nem allergiás) [3].

4. táblázat | Újgenerációs ARIA-GRADE irányelvek [17-19, 21, 28, 30, 32, 36]

\begin{tabular}{|c|c|c|c|}
\hline & GRADE-ajánlás & mHealth-RWE & Pollenkamra-vizsgálatok \\
\hline $\begin{array}{l}\text { A per os antihisztaminok hatáserôssége alacsonyabb, mint } \\
\text { az intranasalis szteroidoké (INCS) }\end{array}$ & [17] & {$[36]$} & \\
\hline DE sok beteg a per os bevitelt részesíti előnyben & $\begin{array}{l}\text { Nincs elég információnk a } \\
\text { betegek választásáról }\end{array}$ & $\begin{array}{l}\text { Nincs elég információnk } \\
\text { a betegek választásáról }\end{array}$ & \\
\hline $\begin{array}{l}\text { Az intranasalis } \mathrm{H}_{1} \text {-antihisztaminok kevésbé hatásosak, } \\
\text { mint az INCS-ek }\end{array}$ & [17] & [36] & \\
\hline Az intranasalis $\mathrm{H}_{1}$-antihisztaminok perceken belül hatnak & {$[17]$} & & {$[30]$} \\
\hline Az INCS-ek erôs hatású kezelési módok & {$[17,19]$} & {$[21,36]$} & \\
\hline $\begin{array}{l}\text { Az INCS-ek hatáskezdete néhány órától néhány napig } \\
\text { terjedhet (a ciklezonid kivételével, amely gyorsabban hat) }\end{array}$ & {$[17]$} & & \\
\hline $\begin{array}{l}\text { Az INCS és a per os antihisztaminok kombinációja nem } \\
\text { hatásosabb, mint az INCS-monoterápia }\end{array}$ & {$[18,19]$} & {$[36]$} & \\
\hline $\begin{array}{l}\text { Az INCS és az intranasalis } \mathrm{H}_{1} \text {-antihisztaminok kombiná- } \\
\text { ciójának hatáseróssége nagyobb, mint az INCS-monote- } \\
\text { rápiáé }\end{array}$ & $\begin{array}{l}\text { IGEN, mérsékelten súlyos/ } \\
\text { súlyos tünetek esetén [19] } \\
\text { Alkalmazásukat a költséghaté- } \\
\text { konyság korlátozhatja: [18] }\end{array}$ & {$[36]$} & \\
\hline
\end{tabular}

Az INCS és az intranasalis $\mathrm{H}_{1}$-antihisztaminok kombinációja perceken belül hatni kezd

A leukotriénantagonisták hatáserőssége alacsonyabb, $\quad[17,19]$ mint az INCS-é

ARIA = allergiás náthával és asztmára gyakorolt hatásával foglalkozó szervezet neve; GRADE = módszer szakmai ajánlások értékelésére, fejlesztésére, megítélésére; INCS = intranasalis kortikoszteroid; mHealth = mobil-egészségalkalmazás; RWE = valós evidencia 
Mindazonáltal a mobiltechnológia fontos eszközzé válik abból a szempontból, hogy jobban megértsük az AR-t, jobban menedzseljük betegeinket, és újszerü információkat nyújt, amelyek korábban, más módszerekkel nem voltak elérhetők [3, 33].

Egyéb 'real-world' evidenciavizsgálatok a mobiltechnológia felhasználásával: Tudomásunk szerint nincs más mHealth-vizsgálat, amely nagy esetszámon értékelte volna a különböző terápiák hatékonyságát.

\section{A beteg- és az orvosi látásmód eltávolodása}

Teljes szétválás tapasztalható az orvos által felírt recept és a beteg magatartása között a pollen kiváltotta AR kezelése során. Az allergológusok döntő többsége felírja a gyógyszereket egy egész szezonra, és azt javasolja páciensének, hogy rendszeresen használja azokat, azokon a napokon is, amikor alig van tünete. A betegek döntő többsége azonban a gyógyszereit igény szerint alkalmazza - amikor az AR-ja nem jól kontrollált -, és nem követi az irányelveket $[3,34]$. Amikor maguk az orvosok a páciensek, ugyanúgy viselkednek, mint más betegek, akik a saját AR-jukat kezelik, és nem a receptek utasításai szerint járnak el, amelyeket felírnak [35].

\section{Újgenerációs ARIA-GRADE iránymutatók}

$\mathrm{Az}$ algoritmus az AR gyógyszeres kezelésének megválasztásában lépcsőzetes szemléletmódot javasol, amely az RWE-vel és a pollenkamrákban végzett vizsgálatok tapasztalataival módosított GRADE-ajánlásokon alapul (4. táblázat) [17-19, 21, 28, 30, 32, 36].

Ez a megközelítés alátámasztja a legtöbb GRADEajánlás érvényességét $\mathrm{AR}$-ben, megerősít néhány feltételezett evidenciát RWE által, és új betekintést is biztosít. Nevezetesen:

- A per os antihisztaminok és az INCS kombinációja nem hatékonyabb együtt, mint az INCS egyedül.

- Az intranasalis $\mathrm{H}_{1}$-antihisztaminok és az INCS kombinációja hatékonyabb (azelasztin-flutikazon-propionát kombináció), mint az INCS önmagában.

- Az intranasalis $\mathrm{H}_{1}$-antihisztamin-tartalmú gyógyszerek perceken belül hatni kezdenek.

- Az INCS és az intranasalis $\mathrm{H}_{1}$-antihisztaminok fix kombinációjának (azelasztin-flutikazon-propionát kombináció, MPAzeFlu) magasabb költségei akkor fogadhatók el, ha más módon nem lehet enyhíteni a tüneteket [18].

Összefoglalva, a GRADE-alapú AR-irányelvek egyeznek több fontos megállapításukban (5. táblázat) [17-19, 23, 28; 37-39].

Az ARIA AR-re javasolt algoritmusának validitását ellenőrizték RCT-kban, megfigyelésen alapuló kutatásokban valós életkörülmények között („real world”) és pollenkamrás vizsgálatokkal is. Az algoritmus egészében megfelelőnek mutatkozott, és nem volt szükség módosításra.
5. táblázat | Farmakoterápiás ajánlások AR-ben [17-19, 23, 28; 37-39]

- Az oralis vagy intranasalis $\mathrm{H}_{1}$-antihisztaminok kevésbé hatékonyak mint az INCS, bármely AR-tünet vonatkozásában [17, 37]. Kétségtelen azonban, hogy hatékonyak számos beteg esetében, akiknek enyhe/középsúlyos tüneteik vannak. Tény az is, hogy számos beteg számára elfogadhatóbb a per os, mint az intranasalis bevitel.

- A per os és az intranasalis $\mathrm{H}_{1}$-antihisztaminok összehasonlításában a javaslatok eltérnek, és egyértelmű következtetést még nem sikerült levonni.

- Súlyos rhinitises tünetek esetén az INCS-alkalmazás jelenti az elsó vonalbeli terápiát, de nem szabad elfelejteni, hogy a teljes hatáserősség eléréséhez néhány nap kell.

- A per os $\mathrm{H}_{1}$-antihisztamin és az INCS kombinációja nem hatékonyabb, mint az INCS-monoterápia [18, 19], habár a kombinált kezelés alkalmazása általános gyakorlat.

- Az MPAzeFlu, amely intranasalis flutikazon-propionát (FP) és aze lasztin (Aze) kombinációja (INCS + INAH) egy eszközben, hatásosabb, mint a monoterápia. Alkalmazása akkor indokolt, ha az INCS önmagában nem kellően hatékony [18, 19, 23] súlyos ARtünetek esetén vagy azoknak a betegeknek, akik gyors tünetcsökkenést akarnak elérni [18, 19]. Pollenkamra-vizsgálattal bizonyították a kombináció gyors hatáskezdetét [28, 38].

- Az összes javasolt gyógyszerelés biztonságosnak tekinthető nor máldózisban alkalmazva. Az első generációs oralis $\mathrm{H}_{1}$-antihisztaminok szedatívak, ezért kerülendők [39], csakúgy, mint a nasalis vasoconstrictorok tartós használata.

- Az intramuscularis depókortikoszteroidok kontraindikáltak AR kezelésében!

$\mathrm{AR}=$ allergiás nátha; INAH = intranasalis antihisztamin; INCS $=$ intra nasalis kortikoszteroid

Ezek az irányelvek bekerülnek az ICP-kbe, és részét fogják képezni az EU Egészségügyi és Élelmiszer-biztonsági Főigazgatósága (DG Santé - The Commission’s Directorate-General for Health and Food Safety) digitalizált, integrált, személyközpontú gondozási anyagainak. Ezek képviselik az ARIA fázis 4.-ben a gondozásmódosítás stratégiáját [1].

\section{'ARIA 2019' - a gondozás lehetőségei allergén-immunterápiában (AIT) [8]}

Az allergénspecifikus immunterápia bevált terápiás lehetőség AR és/vagy asztma kezelésére, akár sublingualis immunterápia (SLIT), akár subcutan immunterápia (SCIT) útján [17, 40-45]. A kettős vak-, placebokontrollált, randomizált klinikai vizsgálatokban (DB-PCRCT) kimutatott hatékonyságot orvosi adatbázisok információival támasztották alá, és alkalmazzák már a mindennapi betegellátásban [46]. A specifikus immunterápia (SIT) Japán kivételével minden országban költségesebb az allergiás rhinitis vagy az asztma más kezelésfajtáinál [47], ezért alkalmazása célzottan, megfelelő kritériumok szerint kiválasztott betegcsoportokban javasolt [48]. Számos AIT-irányelv született [17, 40-45], de a felhasznált, bizonyítékalapú elemzőmódszerek eltérőek, sok közülük túl komplikált, és egyik sem javasol ICP- 
ket. Az 'ARIA 2019' dolgozott ki elsőként ICP-ket SCIT-re és SLIT-re egyaránt [8], amint ezt a jelen dokumentum összefoglalja.

\section{Milyen allergének használhatók?}

- Releváns kivonatok: az immunterápia alkalmazásával kapcsolatos döntésnek az allergénexpozíció ideje alatt jelentkező tüneteken, a szenzitizáltság igazolásán, továbbá jó minőségű, lehetőleg standardizált kivonatok elérhetőségén kell alapulnia [41, 49].

- A nem vizsgált termékekre vonatkozó extrapolációról: valamennyi AIT-re tervezett terméknek hatékonynak és biztonságosnak kell lennie a hatósági elő́rásoknak megfelelően [50]. Az allergénkivonatokat nem lehet generikumként értelmezni. Az EU-ban valamennyi egyedi termék vagy azokat tartalmazó keverék esetén - az EMA (European Medicines Agency) vagy a PEI (Paul Ehrlich Institute) által engedélyezett kivételeken kívül - igazolni kell azok hatékonyságát [50]. A kivételeket a homológ csoportokba tartozó allergének jelentik, amit a klinikailag szignifikáns keresztreaktivitás határoz meg [50].

- Kivonatok keverése: nincs bizonyíték arra nézve, hogy különböző allergének keveréke ugyanolyan hatást vált ki, mint egyedi allergének külön-külön alkalmazása. A keverés a felhígulásukat vagy az allergén degradációját okozhatja. Az EMA ajánlása szerint allergén keveréket használni csak homológ csoportból származó allergének esetén szabad [50]. Egy közelmúltbeli, a NIH (National Institutes of Health) által szervezett aeroallergén-immunterápiás workshopról kiadott jelentésben körvonalazódnak kísérletes elgondolások, amelyek erre a fontos ismerethiányra irányulnak [51].

- Személyre szóló termékek (named patient products, NPPs): számos országban NNP-k vannak forgalomban, amelyekkel a terápia individualizálható, személyre szabható. A módszer azonban további kísérletes bizonyítékokat és RWE-t igényel. Az NNP-ket csak kivételesen engedi forgalmazni az allergénkivonatokra vonatkozó európai szabályozás [44, 52].

- Poliszenzitizált betegek: a betegek gyakran szenzitizáltak (IgE) sok allergénnel szemben (poliszenzitizáció), de többnyire nem mindegyiknek van klinikai jelentősége. Éppen ezért fontos olyan allergéneket használni az immunterápia során, amelyek ténylegesen kiváltják az allergiás tüneteket, és nem olyan túlérzékenységet reprezentálnak, amely a beteg számára potenciálisan érdektelen. Az egyetlen összetevőt tartalmazó immunterápiás készítmények poliszenzitizált betegeknél is hatékonyak lehetnek $[53,54]$.

\section{Biztonságosság}

\section{Subcutan immunterápia (SCIT)}

A típusos reakció (lokális reakció) a bőrpír és a duzzanat az injekció helyén, azonnal vagy néhány órával a beadást követően. Esetenként tüsszögés, nasalis vérbőség, csalánkiütés (szisztémás reakció) is megfigyelhető. A súlyos reakciók nagyon ritkák, de azonnali orvosi beavatkozást igényelnek. A súlyos reakciók általában az injekció beadását követő 30 percen belül kialakulnak, ezért a betegeknek 30 perces várakozási időt kell eltölteniük az orvosi rendelőben az injekció beadását követően.

\section{Sublingualis immunterápia (SLIT)}

$\mathrm{Az}$ allergéncseppeknek vagy tablettáknak kedvezőbb a biztonságossági profiljuk, mint az injekcióknak. A SLIT otthon alkalmazható, az első adagot kivéve, amelyet orvosi felügyelet mellett kell beadni. A mellékhatások döntő többsége helyi reakciókból áll (szájviszketés, ajakduzzanat, hányinger), és spontán csillapodik a kezelés első napjait követően. A helyi reakciók az időtartamuk és az életminőséget befolyásoló hatásuk mértéke alapján rangsorolhatók [55]. Európán kívül bizonyos országokban a SLIT-tablettákhoz mellékelnek egy figyelmeztetést a súlyos allergiás reakciók előfordulásának lehetőségéról, és rutinszerűen ajánlanak adrenalintartalmú autoinjektorokat.

\section{A beteg szempontjai}

A beteg szempontjait mindig figyelembe kell venni a tájékozott döntéshozatal (shared decision-making, SDM) érdekében. A 'real-life' vizsgálatok eredményei az AITvel kapcsolatban ellentmondásosak a tájékozottságot, a tapasztalatokat, az elvárásokat és az elégedettséget tekintve [56]. Az információhiány azonban általánosnak tekinthető, ezért a betegek tájékozottságát, elégedettségét növelö kommunikációt javítani kellene [57].

Az AIT-hez való adherencia alapvető fontosságú annak hatásossága szempontjából. Az adott AIT-protokollhoz való adherencia hiánya és a terápia idő előtti abbahagyása gyakran tapasztalható [58]. Ellentmondóak az eredmények az AIT-adherencia mértékére vonatkozóan, de valószínúleg alacsony [59]. Egy jól szervezett allergológiai ellátás nemcsak a kezelés biztonságosságát növeli, hanem a beteg szoros követését is lehetővé teszi, valamint növeli az adherenciát a kezeléshez [58].

Az SDM-et az aktuális orvosi ismeretek alapján, orvosi-jogi szempontoknak megfelelően kell alkalmazni. Az orvosnak kötelessége a beteget tájékoztatni a kezelési lehetőségekről, azok várható hasznáról és kockázatáról, a szakma szabályainak megfelelően.

\section{Gyógyszerészi szempontok}

A legtöbb beteg saját maga tartja kézben az AR ellátását, a beteg és orvosa közötti kommunikáció nem mindig megfelelő. A gyógyszerészek a betegek számára a leginkább elérhető egészségügyi szakemberek, és az AR az egyik olyan betegség, amelynek kezelését gyakran a gyógyszerész irányítja. Az antihisztaminok jelentős része OTC- (over-the-counter) formában, recept nélkül kap- 
ható, és a beteg orvoshoz nem, csak gyógyszerészhez fordul, az ő segítségét kéri. A gyógyszerész a tünetek alapján ajánl valamilyen antihisztamint, amely OTC-formában elérhető. Ilyenkor gyakran az ár alapján születik döntés, hiszen az eredeti készítmény generikumai jóval olcsóbban érhetők el, mint az eredeti szer. A terápia hatékonyságát gyengítheti, ha a betegek a különböző antihisztaminvegyület-típusokat váltogatva alkalmazzák. Előfordul, hogy a páciens elégedett a kezelés hatékonyságával, folytatni szeretné a megkezdett terápiát, de elfogy az adott készítmény, és azonos nevü termék a patikában éppen nem kapható. Ekkor a gyógyszerész ajánl másik antihisztamint, de megtörténhet, hogy egy ilyen váltáskor nemcsak a termék neve, de a hatóanyaga sem lesz azonos a korábbival (nem biztos, hogy a beteg a korábbi termék nevére jól emlékszik). Esetleg fordítva, a páciens szeretne váltani, mert nem elégedett a korábbi gyógyszerével, de más néven mégis ugyanolyan hatóanyagú terméket kap, amellyel várhatóan ismét nem lesz elégedett. A gyógyszerésznek jól tájékozottnak kell lennie a gyógyszeres kezelésen kívül az AIT-vel kapcsolatban is. A betegek a patikában vásárolják meg az orvos által receptre felírt immunterápiás készítményeket, és a gyógyszerésznek fontos szerepe lehet a betegoktatásban a terápia elönyeire és kockázataira, valamint a terápiához való adherenciára, az AIT irányában való elköteleződésre vonatkozóan. A betegek a gyógyszerészhez is fordulhatnak kérdéseikkel, ha valamire nem emlékeznek pontosan, vagy az orvosi rendelőben elfelejtették megkérdezni. Mellékhatásokról, azok elhárításáról is érdeklődhetnek.

\section{Háziorvosi szempontok}

Sok országban az allergiás betegségek diagnosztikája és terápiája csaknem kizárólag az alapellátás szintjén történik [60]. Az alapellátás folyamatossága, könnyú elérhetősége és holisztikus szemlélete alapvető az AR vezeté-

6. táblázat Precíziós medicina az AIT indikációjában (a [45] és a [62] alapján adaptálva)

1. Pontos diagnózis anamnézissel, bőr-Prick-teszttel és/vagy szérumspecifikus IgE-vel alátámasztva, szükség esetén komponensalapú in vitro diagnosztika (CRD). Néhány ritka esetben provokációs teszt is szükséges lehet.

2. Igazolt indikációk: allergiás nátha, conjunctivitis és/vagy asztma.

3. Az allergiás tüneteket főként a releváns allergénexpozíció váltja ki.

4. Betegcsoport: rossz tüneti kontroll az irányelvek szerint végzett megfelelő farmakoterápia ellenére, a kezeléshez történő megfelelő adherencia allergiaszezonban és/vagy az allergia természetének megváltozása. A mobiltechnológia alapvető fontosságú lehet a betegválasztásban (mHealth-biomarker).

5. A készítmény hatékonyságának és biztonságosságának kimutatása releváns vizsgálatok során.

6. Tájékozott döntéshozatal: a beteg (és a gondozó) szempontjai alapvető fontosságúak.

AIT = allergénspecifikus immunterápia CRD = komponensalapú diagnosztika; IgE = immunglobulin-E sében és a betegközpontú SDM-ben [61]. Nem sok háziorvos kap azonban megfelelő graduális vagy posztgraduális képzést az allergológia területén. A SCIT a primer ellátás területén is alkalmazható lehetne, és - bár van némi rizikója - ezek minimalizálhatók, ha megfelelően képzett háziorvos végzi, gondosan válogatott beteganyagon, megfelelő rendelőben, amely fel van szerelve szisztémás anafilaxiás reakció primer ellátására alkalmas eszközökkel. A hazai gyakorlatban még nagyobb óvatosság ajánlott e tekintetben, mivel az alapellátás gyakran nincs felkészülve anafilaxiás reakció ellátására és a mentőszállítás megszervezése, a sürgősségi osztály elérése - gyakran a nem megfelelő infrastruktúrából adódóan, fóleg vidéki helyszínen - nehézkesebb lehet.

\section{A betegkiválasztás gyakorlati megközelitése allergén-immunterápiában}

Az allergén-immunterápiát specialistának kell felírnia Az SDM alapvető fontosságú AIT-ben. Az AIT sok országban költséges kezelés, és csak bizonyos szempontok alapján válogatott betegek számára lehet felajánlani. A betegeket tájékoztatni kell, hogy az AIT-t fedezi-e az egészségügyi ellátórendszer, valamint a beteg maga is tájékozódhat, hogy biztosítótársaságok nyújtanak-e finanszírozást, így biztosító által térített, esetleg részlegesen vagy teljesen önköltséges-e a terápia.

\section{$\mathrm{Az}$ allergiás betegek kiválasztása allergén-immun- terápiára}

A precíziós medicina szerepét az AIT indikációjában egy szakorvosi találkozó vetette fel $[45,62]$ (6. táblázat).

Allergiás betegségben a precíziós medicina folyamata szerinti megközelítést javasolnak (3. ábra) [48, 62]. Néhány esetben az AIT felajánlható farmakoterápiával jól kontrollált AR-betegeknek is, például akiknél vihar kiváltotta asztmás roham kialakulásával kell számolni [63]. Az AIT még mérsékelt AR esetén is megfontolandó, különösen (de nem kizárólagosan) azoknál a betegeknél, akiknél előfordul asztmaexacerbatio, és földrajzilag veszélyeztett régióban élnek.

\section{Rhinitis és rhinoconjunctivitis serdülőknél és felnőt- teknél}

Az AR farmakoterápiájára vonatkozó irányelvek és szakorvosi közlemények általában az 5. táblázatban összefoglalt megközelítést javasolják [17-19]. Az összes ajánlott gyógyszer biztonságosnak tekinthető normáldózisban alkalmazva. Az 1. generációs oralis $\mathrm{H}_{1}$-antihisztaminok és az intramuscularis depókortikoszteroidok használatát azonban kerülni kell [39]! A 'step-up' és 'step-down' terápia vezetéséhez a MACVIA egy egyszerü algoritmust készített (2/a és 2/b ábra) [22].

\section{Asztma serdülőknél és felnőtteknél}

AIT nem végezhető súlyos és/vagy nem kontrollált asztmás betegeken. Súlyos asztma esetén a biológiai terápia 


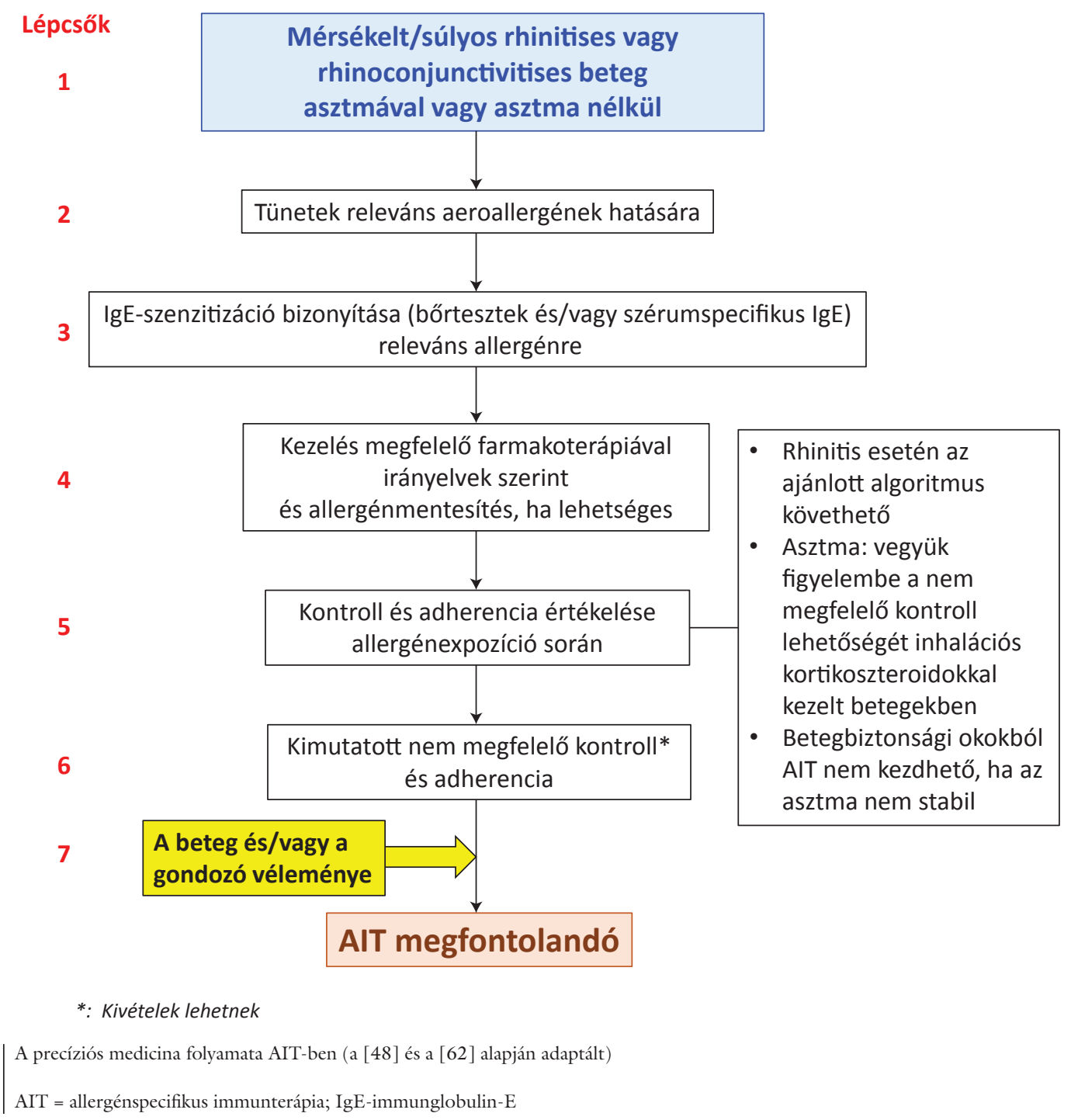

irányában lehet továbblépni, ha az azt megelőző terápiás lépcsők nem jelentettek megoldást. Az allergiás betegségekben alkalmazott AIT azonban egy másik betegpopulációt céloz meg. Az asztmával kapcsolatos aktuális megfontolásokat alább ismertetjük.

Asztmára vonatkozó algoritmus még nincs. A GINA (Global Initiative for Asthma) már jóváhagyta a SLIT-et háziporatka kiváltotta asztmában [64]. A háziporatkára törzskönyvezett SLIT-tabletta tájékoztatójában szerepel [65], hogy (i) a használat előfeltétele, hogy a betegnek az AIT kezdetét megelőző 3 hónapban nem lehetett asztmaexacerbatiója; (ii) azon asztmás betegek terápiájának kezdetét, akiknél akut légúti infekció tünetei lépnek fel, a tünetek megszúnéséig halasztani kell; (iii) az AIT nem alkalmazható az asztma akut exacerbatiójának kezelésére, és a beteget fel kell világosítani, hogy asztmás tüneteinek hirtelen rosszabbodásakor haladéktalanul forduljon orvoshoz; (iv) az atka-AIT eleinte kiegészító terápiaként adható az asztmakontroll-kezelés mellé, az asztmagyógyszerek csak fokozatosan, orvosi felügyelet mellett, az irányelvek ajánlásainak megfelelően csökkenthetók.

Az EU-ban egyelőre más AIT-készítményt nem engedélyeztek, amely primeren indikálható asztmában.

\section{Multimorbiditás}

A multimorbiditás, azaz egynél több allergiás kórkép kialakulása nagyon gyakori allergiás betegekben, az asztmások több mint $85 \%$-ánál AR is fennáll. Másrészt azonban az AR-betegeknek csak 20-30\%-a asztmás. Az AR-multimorbiditás növeli az asztma súlyosságát. Az AIT képes kontrollálni az AR, a conjunctivitis és az asztma multimorbiditást. Egy atka-SLIT-tabletta engedélyezése során a feltételek között a multimorbiditást elfogadták mint terápiás indikációt [65].

Allergén-immunterápia várandósság és szoptatás alatt Nincs arra vonatkozó adat, amely szerint az immunterápia növelné a koraszülésnek vagy a szülés körüli komplikációknak a kockázatát, vagy veszélyeztetné a magzat fejlődését. Mindazonáltal egy estleges anafilaxiás reakció 
és az arra adott kezelés szisztémás hatása veszélyt jelenthet mind az anyára, mind a magzatra nézve, ezért várandósság alatt új terápia nem indítható, de a megkezdett immunterápia folytatható terhesség és szoptatás során is.

\section{Allergén-immunterápia gyermekekben}

Az AIT gyermekek esetében hatékony [66], és a terápia leállítását követően hosszú távon is eredményes lehet. Egy új SLIT-tanulmány [65], egy korábbi füpollenSCIT-tanulmány és egy metaanalízis $[67,68]$ mind azt támasztják alá, hogy az AIT késleltetheti vagy megelőzheti az asztma kialakulását rhinitises gyermekekben. A metaanalízis azonban csak rövid távon mutatott alacsonyabb kockázatot az asztma kialakulására vonatkozóan, a hosszú távú terápiás haszon bizonytalan [68]. Ezért gyermekekben AIT csak olyan mérsékelt vagy súlyos AR esetén kezdhető, amely farmakoterápiával nem kontrollálható megfelelően. Azoknál a gyerekeknél, akik nem asztmásak, figyelembe kell venni az asztma megelözésének lehetőségét, azonban további vizsgálatok szükségesek a pontos indikációk felállításához [40].

\section{Allergén-immunterápia idősebb felnőttekben}

Az idősebb allergiás betegek immunológiai és allergológiai tulajdonságai különböznek a középkorú felnőttekéitôl. Kisszámú tanulmány alapján az AIT hatékony lehet ebben a betegpopulációban. További adatok szükségesek.

\section{Az mHealth szerepe az AIT preciziós medicinális megközelitésében}

A betegkiválasztást segíti a mobiltelefonokban tárolt elektronikus napló használata $[21,69]$ vagy más mHealth-eszközök. Már egyetlen év áttekintése után az orvos fel tudja mérni, hogy (i) fennáll-e mérsékelt/súlyos nem kontrollált betegség, (ii) a tünetek összefüggenek-e pollenszezonnal vagy egyéb allergénexpozícióval, (iii) milyen a farmakoterápiához való adherencia, (iv) megtudható a nem kontrollált tünetek időtartama és (v) befolyása a munkára vagy iskolai teljesítményre. Egy elektronikus klinikai döntéstámogató rendszer segítheti a jövőben a betegek kiválasztását AIT-re.

AIT alatt álló betegek követése: Ugyanez a megközelítés ajánlható az AIT alatt álló betegek követésére is a hatékonyság felmérésére [70].

\section{Következtetések}

Az AIT hatékony terápia az inhalatív allergének által okozott allergiás betegségekben. Alkalmazását azonban korlátozni kell gondosan válogatott betegekre, akik a megfelelő, irányelvek szerint végzett farmakoterápiára rosszul reagálnak, és akik számára a hatékony és költséghatékony AIT elérhető.
Anyagi támogatás: A szerzők a közleménnyel összefüggô anyagi támogatásban nem részesültek.

Szerzői munkamegosztás: K. H.: A magyar helyzet összefoglalása, az 'ARIA 2019' magyar adaptációjának elkészítése, cikkírás, egyeztetés az ARIA-val. H. A.: A cikk átnézése, korrigálása, egyeztetés. N. K.: ARIA-kapcsolattartás, az 'ARIA 2019' magyar adaptációjának elkészítése, cikkírás. A cikk végleges változatát valamennyi szerző elolvasta és jóváhagyta.

Érdekeltségek: A szerzőknek nincsenek érdekeltségeik.

\section{Irodalom}

[1] Bousquet J, Hellings PW, Agache I, et al. Allergic Rhinitis and its Impact on Asthma (ARIA) Phase 4 (2018): Change management in allergic rhinitis and asthma multimorbidity using mobile technology. J Allergy Clin Immunol. 2019; 143: 864-879.

[2] Bousquet JJ, Schünemann HJ, Togias A, et al. Next-generation ARIA care pathways for rhinitis and asthma: a model for multimorbid chronic diseases. Clin Transl Allergy 2019; 9: 44.

[3] Bousquet J, Arnavielhe S, Bedbrook A, et al. MASK 2017: ARIA digitally-enabled, integrated, person-centred care for rhinitis and asthma multimorbidity using real-world-evidence. Clin Transl Allergy 2018; 8: 45.

[4] Bousquet J, Bedbrook A, Czarlewski W, et al. Guidance to 2018 good practice: ARIA digitally-enabled, integrated, person-centred care for rhinitis and asthma. Clin Transl Allergy 2019; 9: 16.

[5] Bousquet J, Anto JM, Annesi-Maesano I, et al. POLLAR: Impact of air POLLution on Asthma and Rhinitis; a European Institute of Innovation and Technology Health (EIT Health) project. Clin Transl Allergy 2018; 8: 36.

[6] Bousquet J, Addis A, Adcock I, et al. Integrated care pathways for airway diseases (AIRWAYS-ICPs). Eur Respir J. 2014; 44: 304-323.

[7] Bosnic-Anticevich S, Costa E, Menditto E, et al. ARIA pharmacy 2018 "Allergic rhinitis care pathways for community pharmacy": AIRWAYS ICPs initiative (European Innovation Partnership on Active and Healthy Ageing, DG CONNECT and DG Santé) POLLAR (Impact of Air POLLution on Asthma and Rhinitis) GARD Demonstration project. Allergy 2019; 74: 1219-1236.

[8] Bousquet J, Pfaar O, Togias A, et al. 2019 ARIA Care pathways for allergen immunotherapy. Allergy 2019; 74: 2087-2102.

[9] Bousquet J, Schünemann HJ, Togias A, et al. Next-generation Allergic Rhinitis and Its Impact on Asthma (ARIA) guidelines for allergic rhinitis based on Grading of Recommendations Assessment, Development and Evaluation (GRADE) and real-world evidence. J Allergy Clin Immunol. 2020; 145: 70-80.e3.

[10] Bousquet J, Pham-Thi N, Bedbrook A, et al. Next-generation care pathways for allergic rhinitis and asthma multimorbidity: a model for multimorbid non-communicable diseases - Meeting Report (Part 1). J Thorac Dis. 2019; 11: 3633-3642.

[11] Márk Zs, Bikov A, Gálffy G. Prevalence of respiratory allergic diseases caused by ragweed in Hungary. [A parlagfü okozta légzőszervi allergiás megbetegedések elófordulása Magyarországon.] Orv Hetil. 2016; 157: 1989-1993. [Hungarian]

[12] Sultész M, Balogh I, Katona G, et al. Trends in prevalence and risk factors of allergic rhinitis symptoms in primary schoolchildren 6 years apart in Budapest. Allergol Immunopathol (Madr). 2017; 45: 487-495.

[13] Sultész M, Balogh I, Katona G, et al. Changes in Prevalence and Risk Factors of Allergic Rhinitis Symptoms in Primary Schoolchildren in Budapest between 2007 and 2013. [Az allergiás nátha prevalenciájának és rizikótényezőinek változása 2007 és 
2013 között budapesti általános iskolások körében.] Fül-orrgégegyógyászat 2019; 65: 91-97. [Hungarian]

[14] Hidvégi P. (ed.) Healthy way of life. [Az egészséges életmód.] Eszterházy Károly Fő́iskola, Líceum Kiadó, Eger, 2015. [Hungarian]

[15] Kadocsa E, Hirschberg A, Vóna I, et al. Professional guideline of the Hungarian Ministry of Human Resources for the treatment of allergic rhinitis. [Az Emberi Erőforrások Minisztériuma szakmai irányelve az allergiás rhinitis ellátásáról.] Eü Közlöny 2015 65(19): 2616-2626. [Hungarian]

[16] Meltzer EO, Wallace D, Dykewicz M, et al. Minimal clinically important difference (MCID) in allergic rhinitis: Agency for Healthcare Research and Quality or anchor-based thresholds? J Allergy Clin Immunol Pract. 2016; 4: 682-688.e6.

[17] Brożek JL, Bousquet J, Baena-Cagnani CE, et al. Allergic Rhinitis and its Impact on Asthma (ARIA) guidelines: 2010 revision. J Allergy Clin Immunol. 2010; 126: 466-476.

[18] Brożek JL, Bousquet J, Agache I, et al. Allergic Rhinitis and its Impact on Asthma (ARIA) guidelines: 2016 revision. J Allergy Clin Immunol. 2017; 140: 950-958.

[19] Dykewicz MS, Wallace DV, Baroody F, et al. Treatment of seasonal allergic rhinitis: an evidence-based focused 2017 guideline update. Ann Allergy Asthma Immunol. 2017; 119: 489-511. e41.

[20] Bousquet J, Devillier P, Anto JM, et al. Daily allergic multimorbidity in rhinitis using mobile technology: a novel concept of the MASK study. Allergy 2018; 73: 1622-1631.

[21] Bousquet J, Devillier P, Arnavielhe S, et al. Treatment of allergic rhinitis using mobile technology with real-world data: the MASK observational pilot study. Allergy 2018; 73: 1763-1774.

[22] Bousquet J, Schünemann HJ, Hellings PW, et al. MACVIA clinical decision algorithm in adolescents and adults with allergic rhinitis. J Allergy Clin Immunol. 2016; 138: 367-374.e2.

[23] Hampel FC, Ratner PH, Van Bavel J, et al. Double-blind, placebo-controlled study of azelastine and fluticasone in a single nasal spray delivery device. Ann Allergy Asthma Immunol. 2010; 105: 168-173.

[24] Kaszuba SM, Baroody FM, deTineo M, et al. Superiority of an intranasal corticosteroid compared with an oral antihistamine in the as-needed treatment of seasonal allergic rhinitis. Arch Intern Med. 2001; 161: 2581-2587.

[25] Glacy J, Putnam K, Godfrey S, et al. Treatments for seasonal allergic rhinitis. [Internet] Agency for Healthcare Research and Quality, Rockville, MD, 2013 Jul. Report No. 13-EHC098-EF.

[26] Allergic rhinitis: developing drug products for treatment. Guidance for industry. U.S. Department of Health and Human Services, Food and Drug Administration, Center for Drug Evaluation and Research (CDER), February 2016, Clinical/Medical Revision 1. Available from: https://www.fdanews.com/ext/resources/files/2016/02/02-12-16-AllergicRhinitisGuidance. pdf? 1520761249 [accessed: May 23, 2020].

[27] Katial RK, Salapatek AM, Patel P. Establishing the onset of action of intranasal corticosteroids: is there an ideal study design? Allergy Asthma Proc. 2009; 30: 595-604.

[28] Bousquet J, Meltzer EO, Couroux P, et al. Onset of action of the fixed combination intranasal azelastine-fluticasone propionate in an allergen exposure chamber. J Allergy Clin Immunol Pract. 2018; 6: 1726-1732.e6.

[29] Patel P, Roland PS, Marple BF, et al. An assessment of the onset and duration of action of olopatadine nasal spray. Otolaryngol Head Neck Surg. 2007; 137: 918-924.

[30] Horak F, Zieglmayer UP, Zieglmayer R, et al. Azelastine nasal spray and desloratadine tablets in pollen-induced seasonal allergic rhinitis: a pharmacodynamic study of onset of action and efficacy. Curr Med Res Opin. 2006; 22: 151-157.

[31] Zieglmayer P, Zieglmayer R, Bareille P, et al. Fluticasone furoate versus placebo in symptoms of grass-pollen allergic rhinitis in- duced by exposure in the Vienna Challenge Chamber. Curr Med Res Opin. 2008; 24: 1833-1840.

[32] Murdoch RD, Bareille P, Ignar D, et al. The improved efficacy of a fixed-dose combination of fluticasone furoate and levocabastine relative to the individual components in the treatment of allergic rhinitis. Clin Exp Allergy 2015; 45: 1346-1355.

[33] Pizzulli A, Perna S, Florack J, et al. The impact of telemonitoring on adherence to nasal corticosteroid treatment in children with seasonal allergic rhinoconjunctivitis. Clin Exp Allergy 2014; 44: $1246-1254$.

[34] Price D, Scadding G, Ryan D, et al. The hidden burden of adult allergic rhinitis: UK healthcare resource utilisation survey. Clin Transl Allergy 2015; $5: 39$

[35] Bousquet J, Murray R, Price D, et al. The allergic allergist behaves like a patient. Ann Allergy Asthma Immunol. 2018; 121: 741-742.

[36] Bédard A, Basagaña X, Anto JM, et al. Mobile technology offers novel insights into the control and treatment of allergic rhinitis: the MASK study. J Allergy Clin Immunol. 2019; 144: 135-143. e6.

[37] Scadding GK, Kariyawasam HH, Scadding G, et al. BSACI guideline for the diagnosis and management of allergic and nonallergic rhinitis. (Revised Edition 2017; First edition 2007.) Clin Exp Allergy 2017; 47: 856-889.

[38] Bachert C, Bousquet J, Hellings P. Rapid onset of action and reduced nasal hyperreactivity: new targets in allergic rhinitis management. Clin Transl Allergy 2018; 8: 25

[39] Church MK, Maurer M, Simons FE, et al. Risk of first-generation $\mathrm{H}_{1}$-antihistamines: a GA2 ${ }^{2} \mathrm{LEN}$ position paper. Allergy 2010; 65: 459-466.

[40] Halken S, Larenas-Linnemann D, Roberts G, et al. EAACI guidelines on allergen immunotherapy: prevention of allergy. Pediatr Allergy Immunol. 2017; 28: 728-745.

[41] Bonertz A, Roberts G, Slater JE, et al. Allergen manufacturing and quality aspects for allergen immunotherapy in Europe and the United States: an analysis from the EAACI AIT Guidelines Project. Allergy 2018; 73: 816-826.

[42] Roberts G, Pfaar O, Akdis CA, et al. EAACI guidelines on allergen immunotherapy: allergic rhinoconjunctivitis. Allergy 2018; 73: 765-798.

[43] Ryan D, Gerth van Wijk R, Angier E, et al. Challenges in the implementation of the EAACI AIT guidelines: a situational analysis of current provision of allergen immunotherapy. Allergy 2018; 73: 827-836.

[44] Pfaar O, Bachert C, Bufe A, et al. Guideline on allergen-specific immunotherapy in IgE-mediated allergic diseases. S2k Guideline of the German Society for Allergology and Clinical Immunology (DGAKI), the Society for Pediatric Allergy and Environmental Medicine (GPA), the Medical Association of German Allergologists (AeDA), the Austrian Society for Allergy and Immunology (ÖGAI), the Swiss Society for Allergy and Immunology (SGAI), the German Society of Dermatology (DDG), the German Society of Oto- Rhino-Laryngology, Head and Neck Surgery (DGHNO-KHC), the German Society of Pediatrics and Adolescent Medicine (DGKJ), the Society for Pediatric Pneumology (GPP), the German Respiratory Society (DGP), the German Association of ENT Surgeons (BV-HNO), the Professional Federation of Paediatricians and Youth Doctors (BVKJ), the Federal Association of Pulmonologists (BDP) and the German Dermatologists Association (BVDD). Allergo J Int. 2014; 23: 282-319

[45] Muraro A, Roberts G, Halken S, et al. EAACI guidelines on allergen immunotherapy: executive statement. Allergy 2018; 73: 739-743.

[46] Zielen S, Devillier P, Heinrich J, et al. Sublingual immunotherapy provides long-term relief in allergic rhinitis and reduces the risk of asthma: a retrospective, real-world database analysis. Allergy 2018; 73: 165-177. 
[47] Meadows A, Kaambwa B, Novielli N, et al. A systematic review and economic evaluation of subcutaneous and sublingual allergen immunotherapy in adults and children with seasonal allergic rhinitis. Health Technol Assess. 2013; 17: 1-322.

[48] Bousquet J, Khaltaev N, Cruz AA, et al. Allergic Rhinitis and its Impact on Asthma (ARIA) 2008 update (in collaboration with the World Health Organization, GA(2)LEN and AllerGen). Allergy 2008; 63(Suppl 86): 8-160.

[49] Bonertz A, Roberts GC, Hoefnagel M, et al. Challenges in the implementation of EAACI guidelines on allergen immunotherapy: a global perspective on the regulation of allergen products. Allergy 2018; 73: 64-76.

[50] Committee for Medicinal Products for Human Use (CPMP). Guideline on allergen products: production and quality issues. EMEA/CHMP/BWP/304831/2007. London, 20 November 2008.

[51] Wheatley L, Wood R, Nadeau K, et al. Mind the gaps: clinical trial concepts to address unanswered questions in aeroallergen immunotherapy. An NIAID/AHRQ workshop. J Allergy Clin Immunol. 2019; 143: 1711-1726.

[52] Bousquet J, Lockey R, Malling HJ, et al. Allergen immunotherapy: therapeutic vaccines for allergic diseases. World Health Organization. American Academy of Allergy, Asthma and Immunology. Ann Allergy Asthma Immunol. 1998; 81: 401-405.

[53] Didier A, Malling HJ, Worm M, et al. Optimal dose, efficacy, and safety of once-daily sublingual immunotherapy with a 5 -grass pollen tablet for seasonal allergic rhinitis. J Allergy Clin Immunol. 2007; 120: 1338-1345.

[54] Durham SR, Emminger W, Kapp A, et al. SQ-standardized sublingual grass immunotherapy: confirmation of disease modification 2 years after 3 years of treatment in a randomized trial. J Allergy Clin Immunol. 2012; 129: 717-725.e5.

[55] Passalacqua G, Baena-Cagnani CE, Bousquet J, et al. Grading local side effects of sublingual immunotherapy for respiratory allergy: speaking the same language. J Allergy Clin Immunol. 2013; 132: 93-98.

[56] Nam YH, Lee SK. Physician's recommendation and explanation is important in the initiation and maintenance of allergen immu notherapy. Patient Prefer Adherence 2017; 11: 381-387.

[57] Chivato T, Álvarez-Calderón P, Panizo C, et al. Clinical management, expectations, and satisfaction of patients with moderate to severe allergic rhinoconjunctivitis treated with SQ-standardized grass-allergen tablet under routine clinical practice conditions in Spain. Clin Mol Allergy 2017; 15 : 1.

[58] Pitsios C, Dietis N. Ways to increase adherence to allergen immunotherapy. Curr Med Res Opin. 2019; 35: 1027-1031.

[59] Bender BG, Lockey RF. Solving the problem of nonadherence to immunotherapy. Immunol Allergy Clin North Am. 2016; 36: 205-213.
[60] Jutel M, Papadopoulos NG, Gronlund H, et al. Recommenda tions for the allergy management in the primary care. Allergy 2014; 69: 708-718.

[61] Pinnock $H$, Thomas $M$, Tsiligianni I, et al. The International Primary Care Respiratory Group (IPCRG) Research Needs Statement 2010. Prim Care Respir J. 2010; 19(Suppl 1): S1S20.

[62] Canonica GW, Bachert C, Hellings $P$, et al. Allergen immunotherapy (AIT): a prototype of precision medicine. World Allergy Organ J. 2015; 8: 31.

[63] O'Hehir RE, Varese NP, Deckert K, et al. Epidemic thunderstorm asthma protection with five-grass pollen tablet sublingual immunotherapy: a clinical trial. Am J Respir Crit Care Med. 2018; 198: 126-128.

[64] Global Initiative for Asthma. Global strategy for asthma management and prevention (2018 update). Available from: https:// ginasthma.org/wp-content/uploads/2019/01/2018-GINA. pdf [accessed: May 23, 2020].

[65] Summary of product characteristics. Acarizax 12 SQ-HDM oral lyophilisate. European Medicines Agency. Available from: https://mri.cts-mrp.eu/Human/Downloads/DE_H_1947_001_ FinalPI.pdf [accessed: May 23, 2020].

[66] Masuyama K, Okamoto Y, Okamiya K, et al. Efficacy and safety of SQ house dust mite sublingual immunotherapy-tablet in Japanese children. Allergy 2018; 73: 2352-2363.

[67] Valovirta E, Petersen TH, Piotrowska T, et al. Results from the 5 -year SQ grass sublingual immunotherapy tablet asthma prevention (GAP) trial in children with grass pollen allergy. J Allergy Clin Immunol. 2018; 141: 529-538.e13.

[68] Kristiansen M, Dhami S, Netuveli G, et al. Allergen immunotherapy for the prevention of allergy: a systematic review and meta-analysis. Pediatr Allergy Immunol. 2017; 28: 18-29.

[69] Bousquet J, Arnavielhe S, Bedbrook A, et al. The Allergic Rhinitis and its Impact on Asthma (ARIA) score of allergic rhinitis using mobile technology correlates with quality of life: the MASK study. Allergy 2018; 73: 505-510.

[70] Pfaar O, Demoly P, Gerth van Wijk R, et al. Recommendations for the standardization of clinical outcomes used in allergen immunotherapy trials for allergic rhinoconjunctivitis: an EAACI position paper. Allergy 2014; 69: 854-867.

(Kraxner Helga dr., Budapest, Szigony u. 36., 1083 e-mail: helga.kraxner1@gmail.com)

A cikk a Creative Commons Attribution 4.0 International License (https://creativecommons.org/licenses/by/4.0/) feltételei szerint publikált Open Access közlemény, melynek szellemében a cikk bármilyen médiumban szabadon felhasználható, megosztható és újraközölhetö, feltéve, hogy az eredeti szerző és a közlés helye, illetve a CC License linkje és az esetlegesen végrehajtott módosítások feltüntetésre kerülnek. (SID_1) 